\title{
UJICOBA HIDRIPONIK TANAMAN KENCUR DAN BAWANG DAYAK
}

\section{(The Trial of Hydroponic on Kencur and Dayak's Onion)}

\author{
Suaibatul Aslamiah \\ Dosen Program Studi Kehutanan Fakultas Pertanian dan Kehutanan \\ Universitas Muhammadiyah Palangkaraya \\ e-mail : Suaibatu199@yahoo.co.id
}

\begin{abstract}
Indonesia has natural resources that are invaluable, especially so many medicinal plants. The purpose of this study to determine: 1) how big is the hydroponics growth the kencur and dayak onion plant without soil media, 2) the influence of nutrients and nutrient concentrations on the growth of hydroponic crops kencur and dayak onions. Benefits of this study medicinal plants in order to attract sympathy and of interest to those who had been planted in general use medium ground, so that hydroponics is an alternative cultivation techniques.

The results showed that the growth of the plants hydroponically kencur less successful. Hydroponics on dayak onion plants it worked with good growth.
\end{abstract}

Keywords : hydroponic, medicinal plants, nutrition

\begin{abstract}
Abstrak
Indonesia mempunyai kekayaan alam yang tidak ternilai, terutama begitu banyaknya tanaman berkhasiat obat. Tujuan penelitian ini untuk mengetahui : 1) seberapa besar pertumbuhan hidroponik tanaman kencur dan bawang dayak tanpa media tanah, 2) pengaruh nutrisi dan konsentrasi nutrisi terhadap pertumbuhan hidroponik tanaman kencur dan bawang dayak. Manfaat penelitian tanaman berkhasiat obat ini agar menarik simpati dan menjadi minat bagi yang selama ini menanam secara umum menggunakan media tanah, sehingga hidroponik adalah sebagai alternatif teknik budidaya.

Hasil penelitian menunjukkan bahwa pertumbuhan hidroponik pada tanaman kencur kurang berhasil. Hidroponik pada tanaman bawang dayak ternyata berhasil dengan pertumbuhan yang baik.
\end{abstract}

Kata kunci : hidroponik, tanaman berkhasiat obat, nutrisi

\section{PENDAHULUAN}

Indonesia saat ini mempunyai kekayaan alam yang tidak ternilai banyaknya, termasuk berbagai jenis tanaman. Banyaknya berbagai jenis tanaman tersebut ada yang digolongkan sebagai tanaman hias, tanaman sayuransayuran dan juga tanaman obat-obatan. Penilaian terhadap tanaman saat ini memang masih sangat relatif, apalagi terhadap tanaman berkhasiat obat.
Masyarakat di Indonesia telah lama mengenal dan menggunakan tanaman berkhasiat obat sebagai salah satu upaya dalam menanggulangi masalah kesehatan. Pengetahuan tentang tanaman berkhasiat obat dan digunakan sebagai obat berdasarkan pada pengalaman yang secara turun temurun telah diwariskan. Pengertian digunakan sebagai obat meliputi semua cara penggunaan yang berdampak fisiko-kimia berupa cara diminum, 
ditempel, untuk bahan cuci, untuk bahan mandi, dan dihirup.

Hydroponic (hidroponik) berarti pengerjaan air yang berasal dari kata hydro (air) dan ponos (kerja). Istilah ini di usulkan oleh W.A. Satchel dengan keberhasilannya. W.F. Gericke mengembangkan teknik baru bercocok tanam dengan air sebagai medium air. Mulanya dipakai istilah aqua culture, namun istilah tersebut sekarang disebut sebagai istilah hydroponiecs.

Budidaya telah dikenal oleh orang-orang Aztek di Amerika Tengah sekitar pada Abad ke-15, yaitu mereka menanam sayur-sayuran , tanaman hias dan pohon buah-buahan di atas danau pada beberapa rakit tanah yang di sebut chinampa. Rakit ini terbuat dari beberapa ikatan batang gelagah. namun tidak ada yang menanam di pekarangan termasuk menanam tanaman obat yang dikenal dengan tanaman keluarga.

Berdasarkan kondisi potensi budidaya hidroponik, kemudian juga perlu dikembangkan penanaman tanaman berkhasiat obat untuk kelurga, maka sangat menarik untuk dilakukan penelitian hidroponik pada tanaman obat keluarga kesehatan yang selama ini secara umum dibudidayakan menggunakan media tanah.

Tujuan dari penelitian ini adalah : a) seberapa besar pengaruh tanaman hidroponik tanpa media tanah, b) bagaimana pengaruh nutrisi terhadap pertumbuhan kencur dan bawang dayak, c) bagaimana konsentrasi nutrisi yang ideal untuk pertumbuhan kencur dan bawang dayak.

Manfaat penelitian ini adalah : a) dengan diketahuinya nutrisi yang tepat untuk kencur dan bawang dayak sehingga dapat bermanfaat bagi penulis pada khususnya dan masyarakat pada umumnya, b) memberikan informasi bahwa hidroponik dapat juga untuk tanaman obat keluarga dan bisa dicoba untuk tanaman obat lainnya.

\section{KAJIAN PUSTAKA}

\section{Tanaman Kencur}

Tanaman kencur memiliki nama ilmiah Kaempferia galanga (Linn.), dengan nama daerah ceuko, tekur (Aceh), kaciwer (Batak) cakue (Minang), cikur (Sunda), sikor (Kalimantan), cekuh ( Bali), cakuru (Makasar), asauli (Ambon) dan ukap (Papua). Sedangkan tanaman kencur juga memiliki nama asing yaitu humala (Benggala), kamung (Burma), prao atau shanna (Cina) dan herba a kemper (Perancis).

Sosok kencur berupa terna berbatang yang tumbuh merumpun, daunnya berbentuk bulat melebar dengan ujung mengecil, daun tumbuh agak merapat dengan permukaan tanah dengan jumlah yang banyak. Warna daun hijau segar dan bertekstur agak tebal. Tangkai daun amat pendek dan berwarna keputihan, bunganya berwarna ungu keputihan berukuran mungil dan berbau harum, bunga muncul di sela daun dan mudah gugur, rimpangnya tumbuh bergerombol dan menjalar, jika dibelah tampaklah daging rimpang dan berwarna putih, kulit rimpang berwarna coklat tua mengkilap. Aroma rimpang 
kencur terasa lembut jika dibandingkan tanaman herbal famili zingiberaceae.

Tempat tumbuh tanaman kencur di Indonesia mudah tumbuh dengan subur. Tanaman yang berasal dari India ini dapat ditanam dalam pot atau halaman pekarangan untuk bumbu dapur atau bahan obat. Tempat tumbuh tanaman kencur yang ditanam sebaiknya sangat cocok berupa tanah gembur, subur, dan sedikit berpasir.

Perbanyakan kencur menggunakan rimpang yang dipilih sudah cukup tua, tetapi masih segar. Rimpang dapat langsung ditanam dan rimpang tersebut akan tumbuh tunas. Sebelum ditanam di tanah, rimpang segar disimpan di gudang selama 1-2 minggu terlebih dahulu agar mengeluarkan tunas.

Kandungan zat kimia pada kencur, yaitu rimpang kencur mengandung asiri yang terdiri atas borneol, methyl p-cumaric acid, cinnamicacid ethyl ester, pentadecana, cinnamic aldehida, camphene, selain itu juga alkaloid, mineral, flavonoid, pati dan gum. Khasiat untuk pengobatan kesehatan menggunakan tanaman kencur, yaitu sebagai : a) obat tetanus, b) obat muntah-muntah, c) obat keracunan jamur, dan d) obat (jamu) beras kencur diminum untuk menambah nafsu makan.

\section{Tanaman Bawang Dayak}

Tanaman bawang dayak memiliki nama ilmiah Eleutherine bulbosa (Mill.) Urb., dengan nama daerah bawang berlian, bawang tiwai, bawang mekah. Juga disebut dengan nama asing changp'ciang (Cina), genggibre
(Spanyol), ingafaera (Swedia), imbir (Rusia), halia (Malaysia), nyabil (Arab), dan ginger (Inggris).

Bagi yang tertarik memanfaatkan bawang dayak sebagai pengobatan alternatif, berikut ciri-ciri bawang dayak yang ternyata mirip dengan bawang merah. Tanaman ini memiliki umbi merah menyala dengan permukaan yang sangat licin. Komposisi daun bersirip ganda dan letak daunnya berpasangan, bentuk daun seperti pita atau garis memiliki bunga putih sehingga dapat dimanfaatkan sebagai tanaman hias (karena indahnya bunga bawang dayak).

Tempat tumbuh bawang dayak mudah sekali dibiakkan dan dapat dipanen dalam waktu singkat. Itulah sebabnya tanaman ini dapat dikembangkan untuk skala industri. Tak hanya itu, tanaman ini dapat tumbuh di berbagai tipe iklim dan jenis tanah. Dapat dibudidayakan dengan cara stek. Jika ingin menanamnya, perbandingan tanah subur dengan kompos adalah 1:1 agar tanaman ini dapat berkembang optimal.

Bawang dayak Eleutherine bulbosa (Mill.) Urb. bisa dikembangkan di daerah dataran tinggi maupun rendah. Sama seperti bawang pada umumnya, bawang dayak juga dikembangkan dari umbinya. Sebagai tanaman liar, bawang dayak sejatinya tetap tumbuh kendati tidak dirawat. Namun, dengan dibudidayakan secara intensif, hasilnya bisa lebih maksimal. Perawatannya juga tergolong mudah dan murah. Hanya perlu air dan pupuk secukupnya. Tanaman ini tahan hama jadi tak perlu pestisida. 
Perbanyakan dan budidaya tanaman ini dengan cara membenamkan umbi ke dalam tanah dengan kedalaman kurang lebih $3 \mathrm{~cm}$ di bawah permukaan tanah yang telah digemburkan, kemudian diberi pupuk secukupnya. Untuk daerah yang datar dan berair perlu dibuatkan bedengan terlebih dahulu supaya akar dan umbi bawang tidak tergenang air dan menjadi busuk. Kalau kebanyakan air nanti akar sama umbinya bisa rusak dan busuk.

Supaya pertumbuhannya lebih cepat, perlu juga diberikan pupuk kandang. Pupuk kandang ini membantu menggemburkan tanah sehingga umbi lebih cepat besar dan lebih mudah saat panen. Apabila menggunakan pupuk kimia, setelahnya tanah perlu disiram dengan effective microorganisme (EM4) agar tidak menjadi keras. Setelah waktu pertumbuhan mencapai 6 bulan, umbi bawang dayak sudah bisa diambil dengan tinggi sekitar $20 \mathrm{~cm}$. Bawang dayak ini dapat dipanen dengan tanda tanaman sudah mengeluarkan bunga.

Sebagai tanaman liar, bawang dayak sejatinya tetap tumbuh kendati tidak dirawat. Dibudidayakan secara intensif, hasilnya tentu akan lebih baik lagi. Untuk mendapat hasil maksimal, ada beberapa hal yang harus diperhatikan antara lain, tanahnya harus gembur dan subur dengan campuran bahan organik, jarak tanam berkisar 10-20 cm. Bawang dayak tahan terhadap hama sehingga tidak perlu memakai pestisida. Hanya, di musim hujan harus mewaspadai jamur yang menyerang umbi karena banyak lembab hingga berjamur. Sementara saat musim kemarau, tidak ada risiko terserang jamur. Disarankan bawang dayak ditanam di lahan terbuka dan tidak ditaruh dalam pot. Ditanam di lahan terbuka, bawang dayak bisa tumbuh maksimal.

Kandungan zat kimia bawang dayak adalah alkaloid, flavonoid, glikosida, saponin, dan tannin. Khasiat Bawang Dayak Manfaat bawang dayak atau yang dikenal juga dengan sebutan bawang berlian, bawang sabrang, bawang tiwai, bawang mekah dan bawang hutan ini, merupakan salah satu tanaman yang sangat banyak manfaatnya bagi kesehatan dan mampu menyembuhkan berbagai macam penyakit. Namun belum banyak masyarakat yang mengetahuinya, Karena tanaman ini hanya ditemukan pada daerah tertentu saja. Khasiat yang terdapat dalamnya yang mampu menyembuhkan berbagai macam penyakit sehingga oleh masyarakat kalimantan banyak digunakan sebagai tanaman obat dipercaya memiliki khasiat untuk mengatasi berbagai macam penyakit. Penemuan khasiat bawang dayak sebagai pengobatan herbal ini sebetulnya berasal dari kebiasaan warga Kalimantan pedalaman yang menggunakan bawang dayak ini sebagai obat berbagai macam penyakit yang kemudian dilakukan penelitian oleh banyak kalangan hingga di temukan banyak sekali manfaat bawang dayak sebagai pengobatan alternatif, Penelitian lebih lanjut mengenai kandungan yang terdapat pada bawang ini menemukan beberapa senyawa aktif yang dapat dikembangkan sebagai tanaman obat herba. 
Menurut hasil penelitian dan analisis kandungan, bawang dayak ternyata memiliki kandungan zat anti bakteri dan antioksidan yang sangat tinggi sehingga dapat mengobati beragam penyakit baik ringan maupun penyakit yang berat. Kandungan anti bakterinya dapat mencegah berkembangnya bakteri, virus dan mikroba lainnya sehingga menghentikan penularan penyakit. Sedangkan kandungan antioksidan yang terkandung di dalamnya mampu menghadapi radikal bebas sehingga efektif sebagai pencegah kanker, pencegah radang, tumor dan pendarahan. Senyawa yang terkandung dalam bawang dayak ini antara lain yakni senyawa aktif berupa naphtoquinones beserta turunannya. Kandungan tersebut yang membuat bawang dayak merupakan antibakteri alami yang ampuh dan dapat dijadikan sebagai pengobatan modern.

Beberapa cara pengolahan bawang dayak antara lain : a) simplisia, b) bubuk/tepung (powder), c) bawang dayak instan, dan d) manisan bawang dayak. Bawang dayak kering, bawang dayak serbuk, maupun bawang dayak segar memiliki kandungan yang hampir sama, cara penyajian bawang dayak ini pun relatif sama. Diantara beberapa penyakit yang dapat diobati dengan bawang dayak adalah : mioma, nefrothiliasis (batu ginjal), radang rektum, hipertensi (tekanan darah tinggi), diabetes militus, sinusitis (radang sinus), asam urat, TBC, hepatitis (penyakit kuning) bottom of form.

\section{METODOLOGI}

\section{Jenis Penelitian}

Penelitian ini merupakan jenis penelitian eksperimen karena adanya perlakuan yang diberikan terhadap objek penelitian.

\section{Waktu dan Tempat}

Penelitian ujicoba hidroponik pada tanaman obat keluarga ini dilaksanakan selama 4 (empat) bulan mulai bulan Agustus sampai Desember 2015. Penelitian ini dilakukan di Jalan Komplek Raden Temanggung Jayakarti, Jalan RTA. Milono Km.6 Palangka Raya.

\section{Alat dan Bahan}

Alat yang digunakan pada penelitian ujicoba hidroponik pada tanaman obat keluarga ini meliputi solder, gelas plastik, gelas ukur, gabus, ember, dan pisau. Sedangkan bahan pada penelitian ujicoba hidroponik pada tanaman obat keluarga ini meliputi pupuk organik, bibit tanaman kencur dan bawang dayak, air, dan media sekam bakar.

\section{Prosedur Penelitian}

1. Menyiapkan Peralatan

a. Mula-mula gabus diberi tanda dengan meletakkan gelas di atas gabus dan dilingkari dengan pulpen bagian yang dilubangi;

b. setelah dilubangi, memotong bagian yang dilubangi dengan jarak $1 \mathrm{~cm}$ dari garis lingkaran pulpen dengan pisau;

c. gelas dilubangi dengan solder bagian bawah dan bagian pinggir dengan 4 lobang membujur ke atas separoh gelas; 
2. Menyiapkan Media Tanam dan Bibit

a. Masukkan sekam bakar yang sudah di lubang setengah gelas yang telah dilubangi.

b. Masukkan bibit yang sudah tumbuh tunasnya lalu tumbuh tunasnya sampai tertutup lalu tutup kembali dengan sekam bakar.

3. Menyiapkan dan Membuat Larutan Pupuk Organik

a. Larutkan 3 tutup botol pupuk organik A (akar) dengan 3 liter air

b. Larutkan 1 tutup botol pupuk organik B (buah) dengan 3 liter air

c. Larutkan 2 tutup botol pupuk cair hidrofarm dengan 3 liter air
4. Memberikan Larutan Nutrisi

Menuang larutan nutrisi pupuk organik ke dalam gabus dengan ketinggian sekitar sekilan dari tutup gabus dan gelas yang ada bibitnya sedalam $1 / 4$ tinggi gelas media tanam.

\section{HASIL DAN PEMBAHASAN}

\section{Hasil Pengamatan Budidaya}

Hasil pengamatan budidaya tanaman kencur dan bawang dayak dengan sistem hidroponik disajikan pada Tabel 1, sedangkan gambaran pertumbuhan budidaya tanaman kencur dan bawang dayak dengan sistem hidroponik disajikan pada Gambar 1 dan 2 .

Tabel 1. Rekapitulasi Pengamatan Budidaya Tanaman Kencur dan Bawang Dayak dengan Sistem Hidroponik

\begin{tabular}{lcl}
\hline \multicolumn{1}{c}{ Jenis Tanaman } & Cara Penanaman & \multicolumn{1}{c}{ Perkembangan Budidaya } \\
\hline 1. Kencur & Hidroponik & Masih tahap tumbuh dan perkembangan \\
2. Bawang dayak & Hidroponik & Tumbuh dengan baik \\
\hline
\end{tabular}

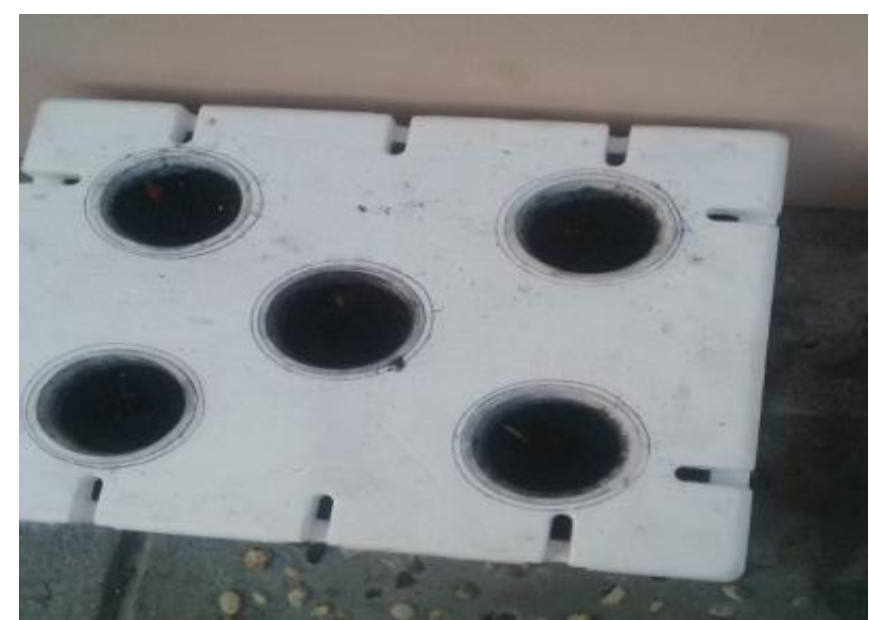

Gambar 1. Gambaran Pertumbuhan Tanaman Kencur dengan Sistem Hidroponik 


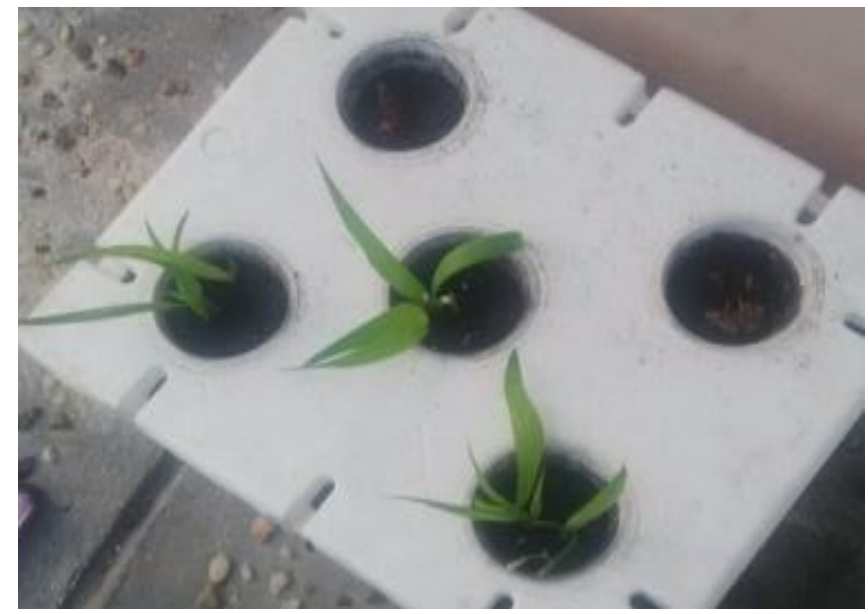

Gambar 2. Gambaran Pertumbuhan Tanaman Bawang Dayak dengan Sistem Hidroponik

\section{Pembahasan}

\section{Budidaya Tanaman Kencur}

Tanaman kencur merupakan tanaman hortikultura yang berkhasiat obat. Selain menjadi rempah (bumbu masak), ternyata berbagai khasiat mampu dimanfaatkan dari rimpang tanaman kencur yaitu sebagai bahan obat tetanus, obat keracunan, dan jamu penambah nafsu makan.

Percobaan budidaya hidroponik pada tanaman kencur (Tabel 1 dan Gambar 1) menunjukkan bahwa pertumbuhan tanaman kencur kurang berhasil, karena masih pada tahap menyesuaikan untuk pertumbuan dan belum bisa dipanen pada umur 4 bulan. Panen untuk konsumsi ternyata mampu dimulai pada umur 6 sampai 10 bulan. Berbagai teknik perlu dilakukan termasuk tahap pemeliharaan, sehingga penyebab tanaman kencur kurang tumbuh sempurna karena : a) sekam bakar kurang banyak, b) campuran nutrisinya kurang sempurna, c) tahap pertumbuhan, dan d) jangka waktu penelitian yang pendek.

\section{Budidaya Tanaman Bawang Dayak}

Tanaman bawang dayak merupakan tanaman hortikultura yang berkhasiat obat. Selain menjadi rempah (bumbu masak), ternyata berbagai khasiat mampu dimanfaatkan dari umbi tanaman bawang dayak yaitu sebagai bahan pengobatan beberapa penyakit yaitu : mioma, nefrothiliasis (batu ginjal), radang rektum, hipertensi (tekanan darah tinggi), diabetes militus, sinusitis (radang sinus), asam urat, TBC, hepatitis (penyakit kuning) bottom of form.

Percobaan budidaya hidroponik pada tanaman bawang dayak (Tabel 1 dan Gambar 2) menunjukkan bahwa pertumbuhan bawang dayak berhasil dengan bagus dikarenakan pemeliharaan dan berbagai dukungan pertumbuhan yang meliputi : a) nutrisinya terpenuhi, b) media sekam bakarnya terpenuhi, dan c) pertumbuhan berhasil dan berkembang dengan baik. 


\section{SIMPULAN DAN SARAN}

\section{Simpulan}

Berdasarkan pengamatan penelitian yang telah dilakukan dan pembahasan, maka disimpulkan bahwa :

a. Budidaya hidroponik tanaman kencur kurang berhasil, karena media tanam berupa sekam bakar kurang banyak, campuran nutrisinya dan dalam jangka waktu yang belum memadai karena seharusnya 6 sampai 10 bulan.

b. Budidaya hidroponik tanaman bawang dayak berhasil tumbuh, karena dapat menyesuaikan dengan media dan nutrisi.

\section{Saran}

Berdasarkan pengamatan penelitian, pembahasan dan kesimpulan penelitian maka perlu dilakukan penelitian selanjutnya yang dapat dilakukan dengan jenis tanaman lain diantaranya tanaman jahe merah, lengkuas dan kunyit putih dengan budidaya secara hidroponik dengan sistem irigasi nutrisi yang mengalir.

\section{DAFTAR PUSTAKA}

\section{Anonim.2012. Bahan Baku Obat Tradisional} dalam Obat Tradisional.com [diakses 29 April 2012].

http://bawangdayak.com/?m=ramuan \&id=admi $\mathrm{n} /$ [diakses 14 agustus 2015, pukul 14.00 WIB].

http://bawangdayakbawangberlian.blogspot.com/2014/01/car a-pengolahan-bawang-tiwai.html/ [diakses 14 Agustus 2015, pukul 14.00 WIB]. http://peluangusaha.kontan.co.id/news/budidaya -bawang-dayak-mudah-dan-murah-2 www bawang dayak-bawangtiwai.blogspot.com/cir-ciri bawangdayak. html [diakses 12 Agustus 2015 pukul 10.25 WIB].

http://www.namalatin.com/bawang-sabrangbawang-dayak [diakses 12 Agustus 2015 pukul 10.25 WIB]

Musliah Fauziah, 2002, Tanaman Obat Keluarga, Jakarta. Penebar Swadaya,

Tim Penulis PS, 1996, Hidroponik Tanaman Hias, Jakarta. Penebar Swadaya.

www bawang dayak.net/ kandungan-bahan sabrang -dan khasiatnya/. diupdate pukul 10.25 wib [diakses 12 Agustus 2015 pukul 10.25 WIB]. 